\title{
Segregation analysis of chronic childhood spinal muscular atrophy
}

\author{
JOHN PEARN \\ From the MRC Clinical Genetics Unit, Institute of Child Health, London
}

SUMMARY A formal segregation analysis for the disease 'chronic childhood spinal muscular atrophy is presented. This disease is also known as 'Kugelberg-Welander disease', 'arrested Werdnig-Hoffmanñ disease', and 'chronic proximal or generalised spinal muscular atrophy'. There were 124 index cases occurring in 115 families. Ascertainment of index patients was by incomplete multiple selection. Three types of segregation analysis were performed: Weinberg Proband, an improved Weinberg Probanळ with a variance corrected formula for differences both in family size and ascertainment probability and a bracketing technique assuming the extremes of both single and of truncate selection. All three methods gave similar results. The improved Weinberg Proband method with corrections for differences in ascertainment and in family size gave a segregation ratio of 0.18 and a $95 \%$ confidence range of 0.11 to 0.25 . The mid-point of the bracketing method assuming extremes of truncate and of single selection was 0.19 . The segregation ratio of that group of children with clinical onset before months of age was $\mathbf{0 . 2 1}$, which does not differ significantly from the 0.25 predicted on the basis $0 \vec{b}$ autosomal recessivity. Evidence is presented to indicate that $25 \%$ of index patients may be due to mo dominant mutations, or phenocopies, or both, and that these occur particularly among sporadic cases with clinical onset over 2 years of age. Empirical risk figures for use in genetic counselling presented, and the literature of the subject is reviewed.

The chronic spinal muscular atrophies (SMA) of childhood cause progressive disability in that important group of children who are physically handicapped by genetic disease. A study of the individual families of children with this condition indicates that both autosomal recessive and autosomal dominant genes are involved. As the gene concerned is common (Pearn, 1974), it is appropriate that a formal segregation analysis be undertaken on family data available for this condition.

Segregation analyses can be used (a) to provide empirical risk figures for use in genetic counselling, even when the type of genetic transmission involved is not elicitible with certainty, and (b) to answer fundamental geinetic questions about the nosology of disease. If such an analysis is to be exploited for the second of these themes, the families which are used as primary data must comprise a clinically unselected series. Without this safeguard, subtle genetically determined clinical differences may lead to differing

Received for publication 2 March 1978 segregation ratios in sub-populations of the series being studied. If this in turn is used to indicate genetie heterogeneity an element of illogical circularity may be introduced.

Recently, a large consecutive series of index cases of chronic childhood SMA has been collected from $\Phi$ major English centres (the Hospital for Sick Children? Great Ormond Street, London, and the Regionat Neurological Centre, Newcastle upon Tyne) whicR function as referral hospitals for children with this disease. The availability of this data has allowed $\$$ formal segregation analysis to be undertaken, not onl\$P to provide empirical risk figures for genetic counse ${ }^{2}$. ling, but also to answer certain hitherto unresolved theoretical questions about the genetic implications of the disease.

\section{Methods}

INDEX CASES

There were 124 index cases (67 females and 57 malesf occurring in 115 families. Ascertainment, clinical, and़ 
family details are published in full in a series of Appendices to a nosological paper by Pearn et al. (1978). The primary family data are also available from the University of London (Pearn, 1974).

An index case was defined as a child ( 0 to 15 years) who had SMA, who had presented to either of the tracing centres at any time between 1961 and 1970, inclusive, and who, being ascertained from either tracing source, independently brought the family to the notice of this study. Cases with an affected parent (2 index cases) were excluded. Cases of acute infantile SMA (termed type I by Emery, 1971) are known to be a separate genetic (Pearn et al., 1973) and clinical (Pearn and Wilson, 1973) entity and were not included. Similarly, the adult onset form of SMA resulting from an autosomal recessive gene is also known to be a separate genetic disease with median age of clinical onset at 35 years of age. The cut-off point of 15 years used in this study did not exclude any possible cases of the chronic childhood form of SMA. Even the most extreme variation reported (for example, see cases Po188 and RO26 of Emery et al., 1976) has not included cases with onset later than 15 years. It can thus be stated with confidence that the series analysed here comprises a consecutive unselected series of chronic childhood SMA.

\section{A SCERTAINMENT}

The interpretation of segregation ratios depends to some extent on the method of ascertainment of index patients and is the subject of many published reports (Li, 1961; Maynard-Smith et al., 1961; Crow, 1965). In the current study only sibships with an affected member were studied, selection thus being incomplete in the genetic sense (Morton, 1962; Crow, 1965). It was appreciated at the outset that the study would result in multiple selection, but that the London series would tend more towards single selection, and the Newcastle series towards truncate selection.

Because of this heterogeneity, the correct approach was to use the Weinberg Proband method (Crow, 1965). This is a direct calculation of the proportion of affected sibs of index patients. C. O. Carter (1973, personal communication) has pointed out that the method is self-correcting whichever method of ascertainment (single, multiple, or truncate) was used to find index patients. If ascertainment was total (that is, truncate in a series identified by affected sibships only), the multiplex family would be picked up by each patient and so counted as many times as there were affected sibs. If ascertainment was low, then the multiplex family would tend to have been picked up by only one patient, and picked up more frequently (in direct proportion to the number of affected sibs) than the simplex family. In either situation, the correct proportion of affected sibs will result.
SEGREGATION RATIOS

If the Weinberg Proband method is used, calculation of the standard error is complex. As a first step, using an admitted oversimplification, the standard error (SE) was calculated using the usual formula:

$$
S E=\frac{p(1-p)}{n}
$$

where $\mathrm{p}$ is the segregation ratio, and $\mathrm{n}$ is the total number of sibs of index patients (Armitage, 1971). Confidence limits (CL) of $95 \%$ were obtained from:

$$
95 \% \mathrm{CL}=\mathrm{p} \pm 1.96 \times \mathrm{SE} \text {. }
$$

As an additional check, the proportions (of sibs affected) born before and after index patients were calculated separately. It was anticipated that this might have revealed an 'artificial' limitation of family size after the birth of an affected child. Many workers have felt that parents are much less likely to try for further children if a handicapped child is born (Bundey and Evans, 1969), and supporting evidence for this was also forthcoming from some sub-groups in this analysis. The effect of this influence, if present, would have been to lower a segregation ratio to below 0.25 in children born before index patients if the disease was a true autosomal recessive one.

There are 2 particular shortcomings of the Weinberg Proband method. The first is that it is not always certain whether second or subsequently affected sibs, who appear also to be index patients, are in fact independently ascertained. If a steady trend is present to designate affected sibs wrongly as index patients, then the segregation ratio would be artificially raised. In theory, the range encompassed for the possible true segregation ratio can be obtained by a bracketing technique (Crow, 1965), assuming the extremes of single and of truncate selection. This technique was also used, but the limits were found to be so wide that little extra practical information resulted.

Secondly, the Weinberg Proband method assigns undue weight to large families; this can be corrected using Fisher's modification of the Proband method (Crow, 1965), by which a more accurate standard error (and hence $95 \%$ confidence range) can be calculated. The segregation analysis was also undertaken with a weighting factor (c) applied to each family size estimate, where

$$
\frac{1}{\mathrm{c}}=1+\pi+\mathrm{p}_{0} \pi(\mathrm{S}-3)
$$

( $\pi$ is the ascertainment probability, and $S$ is sibship size) (Crow, 1965).

To summarise, the Weinberg Proband method was the basic method used. This was supplemented by two 
modifications. The first made no assumptions about the ascertainment of index patients and was used to establish a bracket in which the true segregation ratio lay. The second employed a variance-corrected formula to correct for differences in family size. In practice, the result of each separate method of segregation analysis has given very similar results.

\section{Results}

Table 1 summarises the results of the initial analysis to determine segregation ratios for this disease. On this initial step, the overall segregation ratio by the Weinberg Proband method was found to be 0.18 (SE 0.03 and a $95 \%$ confidence range of 0.13 to 0.23 ). This was significantly different from the figure of 0.25 predicted if transmission by autosomal recessivity was assumed $(0.02>P>0.01)$. There was no significant difference $(P>0.20)$ in this total group between the segregation ratios of sibs born before index patients $(0.17)$ and ratios of those born after $(0.19)$. However, the segregation ratios within families of index cases of early onset (before 9 months and before 12 months of age, analysed separately, see
Table 1) did not differ from the 0.25 predicted assuming autosomal recessivity.

Because of the implications of the low segregation ratio of the total series, however, it was necessary to ensure that the observed initial estimate $\left(p_{0}\right)$ was notes invalidated by chance variations in sibship size:o Details of the appropriate analysis are shown in Tables 2 and 3. From the data in these Tables, $\pi=\overline{\bar{n}}$ 0.457 , and the improved (corrected) estimate of the segregation ratio was 0.18 (with corrected SE 0.034 ) The $95 \%$ confidence range for this corrected segregation ratio was 0.11 to 0.25 . The corrected segregation ratio $(0.18)$ was still significantly differen $\angle$ from 0.25 at the $5 \%$ level $(S M D=1.793 ; 0.05>P>\omega$ 0.02 ). It can be seen that there was virtually no differ ence between the initial and corrected calculations of the segregation ratio $(0.18$ in both instances) ander between those of the standard error $(0.027$ and 0.034,

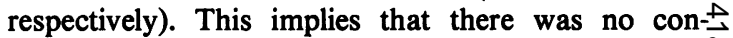
sistent association between the proportion affected and ${ }^{\infty}$ the sibship size for this specific series of chronic SMA patients. Different segregation ratios corresponding to differences in the ascertainment probability $(\pi)$ ando their standard errors have also been calculated; thesed

Table 1 Initial segregation analysis for 124 index patients with chronic childhood SMA. Taken as a total group, the segregation ratio $(0.18)$ was significantly less than the 0.25 predicted on the basis of autosomal recessive inheritance $(P<0.02)$. Weinberg Proband method

\begin{tabular}{|c|c|c|c|c|c|c|c|c|c|c|c|c|}
\hline \multirow[t]{2}{*}{$\begin{array}{l}\text { Index patients } \\
\text { with clinical onset }\end{array}$} & \multicolumn{2}{|c|}{$\begin{array}{l}\text { Sibs born } \\
\text { before index } \\
\text { patients }\end{array}$} & \multicolumn{2}{|c|}{$\begin{array}{l}\text { Sibs born } \\
\text { after index } \\
\text { patients }\end{array}$} & \multicolumn{3}{|l|}{$\begin{array}{l}\text { Total } \\
\text { affected }\end{array}$} & \multicolumn{2}{|c|}{$\begin{array}{l}\text { Difference from } \\
0.25\end{array}$} & \multirow[t]{2}{*}{$\begin{array}{l}95 \% \\
\text { confidence } \\
\text { range }\end{array}$} & \multicolumn{2}{|c|}{$\begin{array}{l}\text { Differences } \\
\text { between grouf }\end{array}$} \\
\hline & Normal & $S M A$ & Normal & $S M A$ & No. & $p$ & $S E$ & SND & $P$ & & $S N D$ & $P$ \\
\hline $\begin{array}{l}\text { Before } 9 \text { months } \\
\text { At } 9 \text { months or later }\end{array}$ & $\begin{array}{l}33 \\
67\end{array}$ & $\begin{array}{r}9 \\
12\end{array}$ & $\begin{array}{l}17 \\
44\end{array}$ & $\begin{array}{r}4 \\
10\end{array}$ & $\begin{array}{l}13 / 63 \\
22 / 133\end{array}$ & $\begin{array}{l}0.21 \\
0.17\end{array}$ & $\begin{array}{l}0.05 \\
0.03\end{array}$ & $\begin{array}{l}0.800 \\
2 \cdot 253\end{array}$ & $\begin{array}{l}P>0.2 \\
P<0.02\end{array}$ & $\begin{array}{l}0 \cdot 11-0.30 \\
0 \cdot 10-0.23\end{array}$ & 0.698 & $\mathbf{P}$ \\
\hline $\begin{array}{l}\text { Before } 12 \text { months } \\
\text { At } 12 \text { months or later }\end{array}$ & $\begin{array}{l}53 \\
47\end{array}$ & $\begin{array}{l}10 \\
11\end{array}$ & $\begin{array}{l}28 \\
33\end{array}$ & $\begin{array}{l}8 \\
6\end{array}$ & $\begin{array}{l}18 / 99 \\
17 / 97\end{array}$ & $\begin{array}{l}0.18 \\
0.18\end{array}$ & $\begin{array}{l}0.04 \\
0.4\end{array}$ & $\begin{array}{l}1.567 \\
1 \cdot 700\end{array}$ & $\begin{array}{r}P>0.05 \\
0.05>P \\
>0.02\end{array}$ & $\begin{array}{l}0 \cdot 10-0.26 \\
0 \cdot 10-0 \cdot 25\end{array}$ & 0.121 & \\
\hline Before 24 months & 95 & 17 & 59 & 14 & $31 / 185$ & 0.17 & 0.03 & 2.589 & $P<0.005$ & $0 \cdot 12-0 \cdot 22$ & - & - \\
\hline Total series & 100 & 21 & 61 & 14 & $35 / 196$ & 0.18 & 0.03 & $2 \cdot 309$ & $\begin{array}{r}0.02>P \\
>0.01\end{array}$ & $0 \cdot 13-0.23$ & - & - \\
\hline
\end{tabular}

Table 2 Segregation analysis for chronic childhood SMA. Distribution of index patients and their sibs by sibship size

\begin{tabular}{|c|c|c|c|c|c|c|c|c|c|}
\hline Sibship size & $\begin{array}{l}\text { No. of } \\
\text { families }\end{array}$ & $\begin{array}{l}\text { Total no. of } \\
\text { members in } \\
\text { sibships }\end{array}$ & $\begin{array}{l}\text { No. with } \\
\text { chronic SMA } \\
(r)\end{array}$ & $\begin{array}{l}\text { No. of index } \\
\text { patients } \\
\text { (a) }\end{array}$ & $a(S-I)$ & $a(r-1)$ & $a(a-I)$ & $\frac{1}{c}$ & $C$ \\
\hline $\begin{array}{l}9 \\
7 \\
6 \\
5 \\
4 \\
3 \\
2 \\
\text { Total }\end{array}$ & $\begin{array}{r}1 \\
1 \\
7 \\
3 \\
12 \\
20 \\
35 \\
79\end{array}$ & $\begin{array}{r}9 \\
7 \\
42 \\
15 \\
48 \\
60 \\
70 \\
251\end{array}$ & $\begin{array}{r}3 \\
1 \\
12 \\
4 \\
16 \\
28 \\
41 \\
105\end{array}$ & $\begin{array}{r}1 \\
1 \\
9 \\
3 \\
14 \\
23 \\
37 \\
88\end{array}$ & $\begin{array}{r}8 \\
6 \\
45 \\
12 \\
42 \\
46 \\
37 \\
196\end{array}$ & $\begin{array}{r}2 \\
0 \\
7 \\
1 \\
6 \\
11 \\
8 \\
35\end{array}$ & $\begin{array}{r}0 \\
0 \\
4 \\
0 \\
4 \\
6 \\
2 \\
16\end{array}$ & $\begin{array}{l}1.95 \\
1.79 \\
1.70 \\
1.62 \\
1.54 \\
1.46 \\
1.37 \\
-\end{array}$ & $\begin{array}{l}0.51 \\
0.55 \\
0.58 \\
0.61 \\
0.64 \\
0.68 \\
0.73 \\
-\end{array}$ \\
\hline $\begin{array}{l}\text { a, number of } \\
\text { S, sibship size } \\
r \text {, total numb } \\
\frac{1}{C}=1+\pi+ \\
\text { For details of }\end{array}$ & $\begin{array}{l}\text { dex patient } \\
\text { of affected } \\
\pi(S-3) \text {. } \\
\text { ethodolog }\end{array}$ & $\begin{array}{l}\text { adividual sibshi } \\
\text { ects in each sib } \\
\text { Crow (1965). }\end{array}$ & dex plus secon & patients); & & & & & \\
\hline
\end{tabular}


Table 3 Segregation analysis (continued) for chronic childhood SMA. Data adjusted for differences in family size by using a weighting factor C (Crow, 1965; Table 2)

\begin{tabular}{|c|c|c|c|c|c|c|}
\hline $\begin{array}{l}\text { Sibship } \\
\text { size } \\
(\mathrm{S})\end{array}$ & $\mathrm{Ca}(S-1)$ & $C a(r-1)$ & $r(r-I)$ & $r(S-I)$ & $C r(r-1)$ & $\operatorname{Cr}(S-1)$ \\
\hline $\begin{array}{l}9 \\
7 \\
6 \\
5 \\
4 \\
3 \\
2 \\
\text { Total }\end{array}$ & $\begin{array}{r}4 \cdot 103 \\
3.352 \\
26 \cdot 470 \\
7.407 \\
27 \cdot 273 \\
31 \cdot 507 \\
27.007 \\
127.119\end{array}$ & $\begin{array}{c}1.026 \\
0 \\
4.116 \\
0.617 \\
3.894 \\
7.535 \\
5.840 \\
23.028\end{array}$ & $\begin{array}{r}6 \\
0 \\
12 \\
2 \\
8 \\
16 \\
12 \\
-\end{array}$ & $\begin{array}{r}24 \\
6 \\
60 \\
16 \\
48 \\
56 \\
41 \\
-\end{array}$ & $\begin{array}{l}3.078 \\
0 \\
7.056 \\
1.234 \\
5 \cdot 192 \\
10.960 \\
8.760 \\
36.280\end{array}$ & $\begin{array}{r}12 \cdot 312 \\
3 \cdot 354 \\
35 \cdot 280 \\
9 \cdot 872 \\
31 \cdot 152 \\
38 \cdot 360 \\
29 \cdot 930 \\
160 \cdot 260\end{array}$ \\
\hline
\end{tabular}

are shown in Table 4. This extra information also established a bracket in which the true segregation ratio must have lain, and provided a range for the true segregation ratio which entailed no assumptions about the ascertainment probability.

The simplest interpretation of the observed segregation ratio of 0.18 was that a majority of families showed autosomal recessive transmission and that, in addition, a small number of sporadic cases as a result either of new dominant mutations or of environmental causes were also present.

To clarify this problem further, segregation analyses were also performed on various subgroupings of the total series (Table 1). One such arbitrary subdivision of index patients was made by considering those with clinical onset before 9 months of age as one group. Here, the segregation ratio of the early onset group (0.21) did not differ significantly from $0.25(\mathrm{P}>0.2)$. A second arbitrary subdivision placed into the early onset group all index patients with clinical onset before 12 months of age. Again, the segregation ratio of this group (0.18) did not differ significantly from 0.25 $(P<0.05)$. The later onset group in each of these trial subdivisions had a segregation ratio $(0.17$ and 0.18$)$ which was significantly less than $0.25(P<0.05$ in

Table 4 Comparisons of different segregation ratios for varying ascertainment probabilities $(\pi)$. The dissimilarity in the 95\% confidence ranges for apparently identical $p$ and $S E$ was due to rounding-off of both measurements in the calculations

\begin{tabular}{|c|c|c|c|c|}
\hline Method & $\pi$ & $\begin{array}{l}\text { Segregation } \\
\text { ratio } \\
(p)\end{array}$ & $S E$ & $\begin{array}{l}95 \% \\
\text { confidence } \\
\text { range }\end{array}$ \\
\hline $\begin{array}{l}\text { Weinberg Proband } \\
\text { Improved Weinberg } \\
\text { Proband (corrected) }\end{array}$ & $\overline{0.46}$ & $\begin{array}{l}0.18 \\
0.18\end{array}$ & $\begin{array}{l}0.03 \\
0.03\end{array}$ & $\begin{array}{l}0.13-0.23 \\
0.11-0.25\end{array}$ \\
\hline $\begin{array}{l}\text { Bracketing method } \\
\text { (i) truncate } \\
\text { selection }\end{array}$ & 1 & 0.23 & 0.03 & $0.16-0.29$ \\
\hline $\begin{array}{l}\text { (ii) single } \\
\text { selection }\end{array}$ & $\rightarrow 0$ & 0.15 & 0.03 & $0.10-0.20$ \\
\hline
\end{tabular}

both instances). It is only when one considers, as a group, children with clinical onset before 24 months of age that the segregation ratio observed $(0 \cdot 17)$ falls significantly below 0.25 for the first time (Table 1). This suggests that the syndrome of SMA due to new dominant mutations (or a phenocopy) do not, in most cases, present before 12 months.

If it is true that SMA with clinical onset before 9 months of age is due, for all practical purposes, to an autosomal recessive gene, it is possible to form a crude estimate of the number of non-recessive index patients in the later onset groups. To do this, the assumption was made that the disease in familial patients was the result of a true recessive gene, and that the patients with non-recessive SMA were to be found among the simplex cases (Crow, 1965). Table 5 shows that in this later onset group (that is, after 9 months of age) of familial index patients, 22 of 66 sibs were affected. This left 67 normal sibs of simplex index patients, occurring in 52 different families. Using $\mathbf{9 5 \%}$ confidence limits, it was shown that the total numbers of normal sibs would be unlikely to have been less than 58 if the group as a whole was transmitted as an autosomal recessive. As 44 of these were sibs of familial index patients (Table 5), this meant that a minimum of 14 were sibs of true recessive cases. Thus, a maximum of 53 (67 minus 14) were sibs of sporadic cases. As the mean numbers of sibs per sibship was 1.3 (excluding index cases), this suggested that a maximum of 41 sibships, and hence isolated index patients, were due to causes other than a recessive gene. In a similar way, it was shown that the minimum number

Table 5 Distribution of sibs of index patients with clinical onset at or later than 9 months of age

\begin{tabular}{lllll}
\hline Index patients & $\begin{array}{l}\text { No. of } \\
\text { index } \\
\text { sibships }\end{array}$ & $\begin{array}{l}\text { No. of } \\
\text { sibs with } \\
\text { SMA }\end{array}$ & $\begin{array}{l}\text { No. of } \\
\text { normal sibs }\end{array}$ & $\begin{array}{l}\text { Total no. } \\
\text { of sibs of } \\
\text { index patients }\end{array}$ \\
\hline Familial & 22 & 22 & 44 & 66 \\
Simplex & 52 & 0 & 67 & 67 \\
Total & 74 & 22 & 111 & 133 \\
\hline
\end{tabular}


of sporadic, non-recessive index patients was 25 . Thus, a working range for the number of non-recessive index patients among the total 124 index patients was between $20.2 \%$ (25 in 124) and $33.1 \%$ (41 in 124), with a working midpoint estimate of $25 \%$.

A similar analysis was undertaken using a cut-off point at 3 years instead of 9 months. Here, a similar analysis indicated that a mean of $19.7 \%$ of late presenting cases was the result of new dominant mutations or phenocopies, or both. It may well be that this late presenting (dominant) group is identical to that suggested by Emery (1971), which he called SMA type III. There is no indication, however, from the segregation analysis that the disease in these latter patients is due to a fully penetrant autosomal recessive gene.

\section{Discussion}

Four other segregation analyses have been undertaken on chronic childhood SMA (Brandt, 1950; Winsor et al., 1971; Bundey and Lovelace, 1975; Emery et al., 1976), the results of which are summarised in Table 6. In addition, segregation ratios are available from 4 other studies (Byers and Banker, 1961; Gamstorp, 1967; Gardner-Medwin et al., 1967; Fried and Emery, 1971). Brandt (1950), in his classic study, used both Weinberg Proband and Sibling methods. There were 52 families in the study but we now appreciate that the series included many cases of infantile SMA (type I SMA of Emery, 1971). Brandt obtained a bracket for his segregation ratio of 0.30 to 0.38 . The major difficulty of interpretation is that designation of index cases was uncertain; for example, there were 52 index cases in the 52 families, which is clearly incorrect in the light of later knowledge. How ever, his figure of 0.38 for the Weinberg Sibling method established a firm upper limit for the true segregation ratio. Brandt noted that this result implie $\overrightarrow{F_{n}}$ genetic heterogeneity in his data, and felt that the bulk? of cases were caused by an autosomal recessive gene.

Winsor et al. (1971) undertook a formal segre gation analysis on 60 families, but again children witt both types of infantile and childhood SMA were included. Ascertainment was thought to be truncaten (all cases in the drainage population were traced, bub tracing was through families with an affected child) These workers used Hogben's method and a variance् corrected formula; no actual segregation ratio was:given, but no significant difference was found from the 0.25 expected on the null hypothesis of autosomat recessivity. These workers did note, however, that the presence of a small number of other forms could noi be excluded. Bundey and Lovelace (1975), in $\overrightarrow{80}$ meticulous study of 33 families with chronic child? hood SMA, gave a segregation ratio of $0 \cdot 17$. No error formula was given, but the appendices to their papep will allow their data to be used cumulatively as furtheo studies are published elsewhere. They noted that theiB data indicated that the bulk of cases were transmitte by an autosomal recessive gene with an admixture of new dominant mutations. An analysis of cases poe senting before 2 years of age gave a segregation ragi of 0.21 , which indicated that the new domingnp mutations were probably concentrated in the lates onset group. This suggestion, confirmed in the presen? study, that the new dominant mutants differ clinicalls: from most of the autosomal recessive cases is of grea

Table 6 Summary of segregation analyses for chronic childhood SMA

\begin{tabular}{|c|c|c|c|}
\hline Study & Segregation ratio & Interpretation & \\
\hline Brandt (1950) & $0.30-0.38$ & $\begin{array}{l}\text { Majority of cases transmitted by } \\
\text { autosomal recessive genes, with } \\
\text { some dominant admixture }\end{array}$ & $\begin{array}{l}\text { Index cases probably } \\
\text { underestimated; } 52 \text { families }\end{array}$ \\
\hline Winsor et al. (1971) & - & $\begin{array}{l}\text { No significant difference from } 0.25 \text {. } \\
\text { SMA of childhood transmitted by an } \\
\text { autosomal recessive gene }\end{array}$ & $\begin{array}{l}60 \text { families used. Both infantile } \\
\text { and juvenile onset cases included }\end{array}$ \\
\hline Bundey and Lovelace (1975) & $\begin{array}{l}0.17 \text { (all cases) } \\
0.21 \text { (cases with onset } \\
\text { before } 2 \text { years of age) }\end{array}$ & $\begin{array}{l}\text { Most cases due to an autosomal } \\
\text { recessive gene, with an admixture } \\
\text { of new dominant mutations. These } \\
\text { found principally among the later } \\
\text { onset cases }\end{array}$ & $\begin{array}{l}\text { A 'pure' series of only chronic } \\
\text { childhood SMA families used for } \\
\text { the analysis; } 33 \text { families }\end{array}$ \\
\hline $\begin{array}{l}\text { Emery et al. (1976) } \\
\text { (International collaborative } \\
\text { study) }\end{array}$ & $\begin{array}{l}0.14-0.23 \text { (all cases) } \\
0 \cdot 16-0.26 \text { (sibs born } \\
\text { after first affected sib) }\end{array}$ & $\begin{array}{l}\text { Autosomal recessive inheritance; } \\
\text { possibility that a few 'sporadic' } \\
\text { cases are due to new dominant } \\
\text { mutations }\end{array}$ & $\begin{array}{l}\text { Authors note that raw data is } \\
\text { incomplete, and that clinical status } \\
\text { of sibs after index case uncertain; } \\
376 \text { sibships; both SMA type I and } \\
\text { chronic childhood SMA included }\end{array}$ \\
\hline Present study & $\begin{array}{l}0.18 \pm 0.03 \text { (all cases) } \\
0.21 \pm 0.05 \text { (cases with } \\
\text { onset before } 9 \text { months) }\end{array}$ & $\begin{array}{l}\text { Autosomal recessive inheritance } \\
\text { for } 75 \% \text { of all cases. Later onset } \\
\text { cases contain bulk of new dominant } \\
\text { mutations or phenocopies }\end{array}$ & $\begin{array}{l}124 \text { index patients; only chronic } \\
\text { childhood SMA families included. } \\
\text { Weinberg Proband method with } \\
\text { corrections for ascertainment } \\
\text { probability and for family size }\end{array}$ \\
\hline
\end{tabular}


help practically in genetic counselling of members of families containing only sporadic cases.

The formal segregation analysis undertaken as part of the international collaborative study of the spinal muscular atrophies (Emery et al., 1976) yielded a segregation ratio of $0.23 \pm 0.02$ using a formula assuming complete ascertainment, and $0.14 \pm 0.01$ assuming single incomplete ascertainment. They also estimated ratios for sibs born after the first affected sib, giving a bracket of 0.16 to 0.26 , but this method gives an artificially high estimate of the segregation ratio (C. O. Carter, 1973, personal communication). These workers noted that the results indicated that an autosomal recessive gene was involved, but that it was possible that a few 'sporadic' cases might have been the result of dominant new mutations. They noted that the results from such a multicentre study must be interpreted with caution in the light of difficulties with varying criteria for (a) completeness of data, (b) examination of sibs of index cases, and (c) interfamilial heterogeneity.

The current study has produced results strikingly similar to those of Bundey and Lovelace (1975), which also selected only index patients with the defined disease of chronic childhood SMA. There is now a considerable body of mutually supporting evidence to indicate that chronic childhood SMA is due unequivocally to an autosomal recessive gene, with an admixture of new dominant mutations (or phenocopies). The $25 \%$ estimate from this study is higher than that generally considered for this non-recessive group. This may be because other series have combined in the segregation analyses both acute SMA (type I) and the chronic childhood disease. As the acute fatal infantile disease is probably exclusively transmitted by an autosomal recessive gene, inadvertent inclusion of such index cases will tend to swamp the effects of a minority of dominant mutations, or at least make their relative proportion appear less. A decision as to whether these non-recessive cases are fresh dominant mutants must await a segregation analysis on their children.

The author thanks Professor C. O. Carter for advice and support and Dr Derek Roberts for advice about the bracketing technique used. This work was undertaken during tenure of the Florey Fellowship, The Royal Society, which the author gratefully acknowledges.

\section{References}

Armitage, P. (1971). Statistical Methods in Medical Research, 1st ed., pp. 89-114. Blackwell Scientific Publications, Oxford and London.

Brandt, S. (1950). Werdnig-Hoffmann's Infantile Progressive Muscular Atrophy, p. 100. Ejnar Munksgaard, Copenhagen.

Bundey, S., and Evans, K. (1969). Tuberous sclerosis: a genetic study. Journal of Neurology, Neurosurgery and Psychiatry, 32, 591603.

Bundey, S., and Lovelace, R. E. (1975). A clinical and genetic study of chronic proximal spinal muscular atrophy. Brain, 98, 455-472.

Byers, R. K., and Banker, B. O. (1961). Infantile muscular atrophy. Archives of Neurology, 5, 140-164.

Crow, J. F. (1965). Problems of ascertainment in the analysis of family data. In Genetics and the Epidemiology of Chronic Diseases. Public Health Service Publications No. 1163. Ed. by J. V. Neel, M. W. Shaw, and W. J. Schull, pp. 23-44. Public Health Service, Washington.

Emery, A. E. H. (1971). Review. The nosology of the spinal muscular atrophies. Journal of Medical Genetics, 8, 481-495.

Emery, A. E. H., Davie, A. M., Holloway, S., and Skinner, R. (1976). International collaborative study of the spinal muscular atrophies. Journal of the Neurological Sciences, 30, 375-384.

Fried, K., and Emery, A. E. H. (1971). Spinal muscular atrophy type II. Clinical Genetics, 2, 203-209.

Gamstorp, I. (1967). Progressive spinal muscular atrophy with onset in infancy or early childhood. Acta Paediatrica Scandinavica, 56, 408-423.

Gardner-Medwin, D., Hudgson, P., and Walton, J. N. (1967). Benign spinal muscular atrophy arising in childhood and adolescence. Journal of the Neurological Sciences, 5, 121-158.

$\mathrm{Li}, \mathrm{C}$. C. (1961). Index case and recessive proportion. In Human Genetics. Principles and Methods, chapter 5, p. 58. McGraw-Hill, New York.

Maynard-Smith, S., Penrose, L. S., and Smith, C. A. B. (1961). Mathematical Tables for Research Workers in Human Genetics, pp. 14-15. Churchill, London.

Morton, N. E. (1962). The ascertainment probability. In Methodology in Human Genetics, pp. 26-28. Ed. by W. J. Burdette. Holden-Day, San Francisco.

Pearn, J. H. (1974). The Spinal Muscular Atrophies of Childhood. $A$ Genetic and Clinical Study. Ph.D Thesis, University of London. Pearn, J. H., Bundey, S., Carter, C. O., Wilson, J., GardnerMedwin, D., and Walton, J. (1978). A genetic study of subacute and chronic spinal muscular atrophy in childhood. Journal of the Neurological Sciences, 37, 227-248.

Pearn, J. H., Carter, C. O., and Wilson, J. (1973). The genetic identity of acute infantile spinal muscular atrophy. Brain, 96, 463-470.

Pearn, J. H., and Wilson, J. (1973). Acute Werdnig-Hoffmann disease. Archives of Disease in Childhood, 48, 425-430.

Winsor, E. J., Murphy, E. G., Thompson, M. W., and Reed, T. E. (1971). Genetics of childhood spinal muscular atrophy. Journal of Medical Genetics, 8, 143-148.

Requests for reprints to Dr John Pearn, Department of Child Health, Royal Children's Hospital, Herston, Brisbane, Queensland 4029, Australia. 